\title{
Marcin Urbański*
}

\section{STANISLAW CIOSEK MEETING WITH THE POLISH AMBASSADOR IN THE SOVIET UNION AND RUSSIA}

The $5^{\text {th }}$ of February 2015 was the day in which the Casimir Pulaski Foundation and the Public Library of the City of Warsaw in cooperation with the Polish Society of Political Science initiated a series of debates on contemporary Russia.

Already in the beginning of the event, Library Director Michał Strąk declared that Thursday's meetings devoted to the Russian Federation will sign up in the calendar of the library and will be held every first Thursday of the month. The declaration has met with great approval of the gathered audience.

Not coincidentally, during the difficult Polish - Russian relations and conflict in the Ukraine, the honored guest of discussion was Stanislaw Ciosek - Polish Ambassador in the Soviet Union and the Russian Federation in the years 1989-1996, the author of "Memories (Not Necessarily) Diplomatic". In the interview he was accompanied by Maciej Raś (PhD) from the Institute of International Relations at the University of Warsaw and - as a moderator - Agnieszka Bryc (PhD) from the Department of Political Science and International Studies at the University of Nicolaus Copernicus.

On this day, also graced with their presence Professor Longin Pastusiak - deputy, senator, Speaker of the Senate, Jerzy Maria Nowak - former Polish Ambassador to NATO, Jacek Potocki - journalist, commentator and foreign correspondent and also many students and residents of Warsaw.

The meeting was inaugurated with a short introduction by Agnieszka Bryc about the contents of Ambassador Ciosek's book, which in large part is devoted to the essence of Russian policy, about what Russia really is and why, especially today, there are problems in Polish-Russian relations. Responding to a question with the words of the author of the book that "[...] contemporary problems arise from Russia's disappointment with the West”, she started a very interesting discussion.

Because of well-known reasons as first spoke Ambassador Ciosek, referring to the question posed by his previous speaker, namely whether Russia will be attached to Western civilization, creating a common home from Lisbon to Vladivostok, if in fact it is the essence of today's problems. In his reply, the diplomat referred to the behavior

* Marcin Urbański, National Security Faculty, National Defence University in Warsaw. e-mail:m.urbanski@aon.edu.pl. 